\title{
Virchows Archiv \\ für \\ pathologische Anatomie und Physiologie \\ und für \\ klinische Medizin.
}

\author{
Herausgegeben \\ von \\ Johannes Orth, \\ redigiert \\ von
}

Oscar Israel.

Band 179.

Folge XVII. Band IX.

Mit 16 Tafeln und 15 Textfiguren.

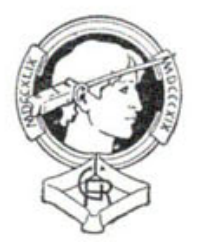

B e rlin

Druck und Verlag von Georg Reimer 1905. 
